in the recently issued volume for 1886. I imagine there are very few general geologists who desire to possess 15 plates of one species of plant, however curious and interesting that plant may be. Again, the appearance of seven plates devoted to the horns of Deer is not likely to be welcomed by any but a few experts. These 22 plates would have illustrated 50 or 100 species of Mollusca, and there are many hundreds of such fossils awaiting illustration.

Why are the Mollusca so neglected? It is true that in this volume we have the first parts of two memoirs on Jurassic Mollusca, but one of these parts is wholly taken up with stratigraphical details which, thongh unquestionably useful, might perhaps have been condensed or printed elsewhere; this, however is a minor point, and every one will welcome Mr. Hudleston's Monograph. Cannot the Council induce other palæontologists to prepare similar monographs on the Cephalopoda, Gasteropoda, and Pelecypoda of the Cambrian, Ordovician, Silurian, Devonian, Carboniferous, Cretaceous, Eocene, and Oligocene formations?

I can testify that the synonomy of some of the commonest Chalk fossils is in the utmost confusion; and that Monographs of the Cretaceous Mollusca would be welcomed by many amateur and professional geologists. When will Mr. Wiltshire give us his promised contribution? I feel sure that if this and other Molluscan Monographs were produced, and if those relating to fossil plants and bones were deferred, the publications of the Society would be used by a much larger number of persons, and consequently that many more geologists and local institutions would decide to become subscribers.

Harwell, Berks, August 5.

A. J. Jukes-Brownk.

\title{
THE GLACIAL DEPOSITS OF SUDBURY, SUFFOLK.
}

Srn,-I owe an apology to Mr. Jukes-Browne for having omitted any reference to the action of coast-ice in my paper upon the Glacial Deposits of Sudbury in the June Number of the Magazine (pp. 262270 ). In considering the suggestions made to account for the contortion of drift deposits, I should have mentioned the grounding of true or false icebergs, or of coast-ice. Nevertheless, it seems to me that the arguments I brought forward against the contortion having been produced by icebergs apply equally to the case of coast-ice.

Unless we are prepared to admit that the drifts were actually frozen into the coast-ice at the time that the contortion was produced in them (and I fail to see how such could be the case, considering the uniformity of succession and characters of the drift over a considerable area), we must suppose that they were deposited on the sea-floor before the exertion of pressure by this ice. If so, it is difficult to see why the drifts were not frozen as well as the underlying Tertiary rocks, for these drifts are of some thickness, and considerable time must have elapsed during their formation. If they were so frozen, the Tertiary beds ought to be affected in the same manner as the drifts, which is not the case. 
If the drifts were not frozen, I cannot understand the production in them of overfolds of considerable horizontal extent (such as that shown at the south end of Mr. Green's pit), without any obliteration of the planes of deposition.

Mr. Jukes-Browne speaks of the drifts as being pushed along in a 'partially-frozen state.' Even if contortion can be produced by coastice in deposits under such conditions, I cannot conceive that the order of succession of the deposits should be so constant as it is in the Sudbury area, upon this hypothesis. Surely the incoherent portions of the drift would become churned up, so that we should find masses of boulder-clay, gravel, and loam mingled together, and having their divisional planes obliterated. I have seen no signs of such in the area under consideration.

In asserting that contortions occur "in the accumulations which lie on the summits of ridges," I used the term 'summits' not for the highest points, but for the upper portions of the major ridges, and I referred to Mr. Green's pit and the pits near the cemetery. These pits are situated at the upper parts of major ridges, and the contortions are seen in Mr. Green's pit to lie against a minor ridge. At the same time I do not wish to assert that all the contortions were caused by the inequalities elose to which they now lie.

I regret that my summing up should appear biassed in favour of one explanation. I visited the Sudbury area with little practical knowledge of the East Anglian drifts. Having read much of the literature bearing upon these drifts, including Mr. Jukes-Browne's lucid papers, $I$ started my examination with a strong bias in favour of their marine origin. As I was gradually led to abandon this view, I considered it worth while to state the evidence which weighed with me, but brought forward my reasons as an advocate, and not as a judge. I should certainly not venture to make a charge to a jury with the evidence derived from so limited an area.

I take this opportunity of calling attention to one or two inaccuracies in Fig. 1 of my paper. The Crag mass $C^{\prime}$ should be separated from the filled-in ground $D$ by a little gravel; the junction of the Thanet sand and chalk in the isolated patch at the south end of the pit should be in the same straight line with that of the main portion, and the top and base of the Thanet sand layer are much more even than represented in the diagram.

St. John's Coll., Cammridgr. Aug. 6,1887 .

\section{THE CORTLAND ROCKS.}

Sir,-Dr. Callaway, in combating the 'metamorphic' origin of the rocks of the 'Cortland Series,' does not appear to be aware that Prof. Dana has materially modified his earlier opinion on this point. After examining some new railway cuttings, he was convinced that the hornblendic and augitic rocks are of true eruptive origin, and although he does not find that the new sections throw any light on the origin of the 'soda-granite,' his former line of argument is evidently much weakened (Amer. Journ. Sei. 3, vol. xxviii. p. 384, 